\title{
The Rite of Veneration of the Icon of the Archangel Michael in the Village of Ishimka in Bolsheuluisky District of Krasnoyarsk Krai
}

\author{
Aleksandr V. Trofimov and Valentina V. Chaíkina* \\ Dmitri Hvorostovsky Siberian State Academy of Arts \\ Krasnoyarsk, Russian Federation
}

Received 13.03.2020, received in revised form 28.05.2020, accepted 05.06.2020

\begin{abstract}
The article considers the issue of preserving an authentic tradition. It is the rite of veneration of the icon of the Archangel Michael which has been observed in the village of Ishimka in Bolsheuluisky district of Krasnoyarsk Krai until recently. The narration of this rite by Maria Illarionovna Rantseva was recorded during a folklore expedition in 2012. She also sang a spiritual verse about the Archangel Michael, which was performed in the context of the rite of veneration of his icon. It is for the first time that this material is given a focus of analysis in our research, the fact proving its relevance and scientific novelty. Since the Russian folklore tradition is currently rapidly fading, the materials recorded from Maria Illarionovna Rantseva are priceless.

The Archangel Michael is one of the most beloved representatives of the Heavenly world by the Russian people. He is considered the main archangel. In Hebrew his name means "like God". In Orthodoxy he is called the Archistratigus, since he is the head of the Heavenly host of angels and archangels. In addition, the Archangel Michael is regarded as the patron saint of travellers. In Russia, the Archangel Michael was also prayed for help in moving to a new place of residence. Many Russian churches are named after the archangel, and every church has icons with his image. In Russian iconography, there are many local schools. The icon of the Archangel Michael, which is regarded in this article, was written by a master of the Belarusian school of iconography. At the beginning of the $20^{\text {th }}$ century, this icon was moved by the peasants of one of the Belarusian villages to the Siberian village of Ishimka. The rite of veneration of the icon of the Archangel Michael was preserved in this village until the beginning of the $19^{\text {th }}$ century.
\end{abstract}

Keywords: the Archangel Michael, icon, rite, tradition, Siberia, Ishimka, M.I. Rantseva.

Research area: theory and history of art.

Citation: Trofimov, A.V., Chaikina, V.V. (2020). The rite of veneration of the icon of the Archangel Michael in the village of Ishimka in Bolsheuluisky district of Krasnoyarsk Krai. J. Sib. Fed. Univ. Humanit. Soc. Sci., 13(6), 979-988. DOI: 10.17516/1997-1370-0621.

(C) Siberian Federal University. All rights reserved

* Corresponding author E-mail address: valentina.chaykina@yandex.ru 


\section{Introduction}

The study of folklore materials is one of the most relevant fields of knowledge in science, since it is associated with the preservation of traditional culture, which contributes to strengthening of national identity. Nowadays the issue of keeping an authentic tradition is one of the most urgent ones. Since the folklore tradition is currently rapidly fading, it is all the more important to study recently recorded materials that are still sometimes found during folklore expeditions. The materials about the rite of veneration of the icon of the Archangel Michael and the spiritual verse "Mikhailo Arkhangélo" "Michael the Archangel"), which existed in the context of this rite, are among such valuable findings. These truly priceless materials were recorded in the Siberian city of Achinsk, the materials being narrated by Maria Illarionovna Rantseva, who was born in 1934 and lived for a long time in the village of Ishimka in Bolsheuluisky district of Krasnoyarsk Krai.

The materials of this article are Maria Illarionovna Rantseva's narrations, recorded during Alexander Trofimov's folklore expedition (Rantseva, 2012). The concepts and ideas associated with the image of the Archangel Michael form the object of the research. The subject of the research is the embodiment of the Orthodox tradition of veneration of icons in a certain local rite, observed in the village of Ishimka in Bolsheuluisky district of Krasnoyarsk Krai. The study considers this rite for the first time, which ensures the novelty and scientific relevance of the research.

The goal of this article is to consider the characteristic features of the rite of veneration of the icon of the Archangel Michael in the Orthodox tradition. It has been achieved due to a set of consistently regarded tasks, the tasks being the following ones:

- review of patristic literature devoted to the discussions about the place and functions of the Archangel Michael in the Heavenly hierarchy;

- description of characteristic features of the icon of the Archangel Michael, kept in Nikolsky temple in the village of Bolshoi Ului;
- clarification of the specifics of the local version of the rite of veneration of this icon, which was observed in the village of Ishimka in Krasnoyarsk Krai.

The designated range of tasks implies the study of a large body of works related to various fields of knowledge. In the course of this research, it became clear that in Orthodoxy there was a developed cult of veneration of the Archangel Michael. It caused the researchers' interest at the end of the $19^{\text {th }}$ century. So, in 1892, the work by the Orthodox historian V.V. Bolotov "Mikhaĭlov den'. Pochemu sobor sv. Arkhistratiga Mikhaila sovershaetsia 8 noiabria" (Michaelmas. Why is the Synaxis of St. Michael celebrated on November 8) was published (Bolotov, 1892). At the beginning of the $19^{\text {th }}$ century, Russian scholars also wrote a number of dissertations, among which there are the works by O.N. Afinogenova (Kul't Arkhangela Mikhaila $v$ Vizantiiskoi Imperii [The Cult of the Archangel Michael in the Byzantine Empire] (Afinogenova, 2008)) and P.A. Tychinskaia (Obraz Arkhangela Mikhaila groznykh sil voevody v russkom iskusstve pozdnego srednevekov'ia [The image of the Archangel Michael, a voivode of the threatening forces, in Russian art of the late middle ages] (Tychinskaia, 2012)). The researchers' interest in the image of the Archangel Michael emphasizes the relevance of the topic of the article.

Apocryphal Christian literature also grasped the researches' special attention (refer to "The Gospel of Nicodemus" (Apokrificheskie Evangeliia, 2011)). Besides, we referred to the texts from the Bible and to the works by the Holy Fathers of St. Gregory Palamas Orthodox Church (2006), Dionysius the Areopagite (2002), et al.

The comparative and descriptive methods serve the methodological basis of our research

\section{The Place and Functions of the Archangel Michael in the Celestial Hierarchy}

On April 18, 1907, a long (longer than a month) pedestrian crossing of residents from the Belarusian village of Khodun in the Mogilev province to the village of Ishimka in Bolsheu- 
luisky district of Krasnoyarsk Krai was over. Moving from Belarus to Siberia, the peasants took two icons with the image of the Archangel Michael with them and took turns to carry them. They firmly believed that the Archangel Michael would protect them during their long journey, because this archangel is considered the guardian of travellers. Thus, in one of the apocryphal gospels, the authorship of which is attributed to Nicodemus, a New Testament secret follower of Jesus Christ, it is said that after the descent into hell Jesus Christ entrusted Michael with the mission to accompany the souls of the dead righteous men on their way to the throne: "The Lord, holding Adam by the right hand, delivered him to Michael the Archangel and all the saints followed Michael the Archangel and he led them all into Paradise" (Apokrificheskie Evangeliia, 2011: 205). Almost all the prayers addressed to the Archangel Michael contain the following words: "Preserve us, Archangel, from all enemies visible and invisible". One of the icons moved by the peasants of the Belarusian village to Siberia is still in Nikolsky temple of the village of Bolshoy Ului. The second icon, unfortunately, burned down.

In the Russian Orthodox tradition, the veneration of the image of the Archangel Michael takes a special place. He is the hero of hagiographic, folklore, chronicle, and apocryphal works. A wide range of liturgical texts and writings with military themes are dedicated to him. Many temples and churches were built in his honor. Thus, one of the first Kiev churches - St. Michael's Golden-Domed Monastery (the beginning of the $12^{\text {th }}$ century) - was consecrated in honor of the Archangel Michael. Later, quite a lot of churches were built in Russia in the name of the archangel. Only in Moscow six St. Michael's churches were built. The Cathedral of the Archangel in the Kremlin (15051508), the Alexis' Archangel Michael Monastery of the Chudov Monastery in the Kremlin (1501-1504), the Church of Saint Michael the Archangel of the Donskoy Monastery (18061809) are among them.

On the territory of Krasnoyarsk Krai, the temples named after the Archangel Michael are found almost everywhere. These are, for example, the Temple of the Archangel Michael and
His Miracle in Khonekh in Krasnoyarsk, the Temple of the Archangel Michael in Zheleznogorsk, the Temple of the Archangel Michael in the village of Zykovo in Berezovsky district, etc. It is obvious that for the Russian people he was a particularly revered saint of the celestial world. Russian traditional folklore is literally permeated with the appeals to this archangel. For example, there are the following lines in the epic about Mikhail Potyka, a Russian hero, a dragon fighter:

И сговорит тут старая калика седатая: - Ай же ты Михайла Потык сын Иванович! Придешь как ко городу ко Киеву, Сострой-ко церковь-ту Миколину Своему ты Ангелу, Михаилу Архангелу (Gil'ferding, 1873: 200).

[I sgovorit tut staraia kalika sedataia: - Ai zhe ty Mikhaila Potyk syn Ivanovich! Pridesh' kak ko gorodu ko Kievu, Sostroi-ko tserkov'-tu Mikolinu Svoemu ty Angelu, Mikhailu Arkhangelu].

The date of the celebration of the day of the Synaxis of the Archangel Michael and the other bodiless powers falls on November 8 (21). This celebration was established at the beginning of the IV century at Laodicean Cathedral. The fact leads to the following question: why do Orthodox Christians appeal to the Archangel Michael on this particular day? The answer to it is related to the symbolism of the numbers 8 and 9 . Thus, the celebration of the holiday in November is symbolic: November is the ninth month if counting from March. In ancient times, it was with the first spring month when a new year began. As for figure 9, it corresponds to the number of the nine ranks of the celestial hierarchy. The eighth day of the month is focused on the Council of all the powers of Heaven, which will be held on the day of the God's Last Judgment. The Holy fathers call it "the eighth day", as it is after this age, which is counted in weeks of days, when "the eighth day" comes. It is the day of the second coming of Christ, who will appear in his glory with all the holy angels led by Archangel Michael. 
In Hebrew St. Archangel Michael means "like God". It is he who is appointed by the Lord above all nine ranks of the celestial hierarchy. It is he who brought the arrogant fallen spirits and Dennitsa (the devil, the Satan, the rebel against God), who was the most important of them, down from the Sky.

On the icons, the Archangel Michael is depicted in his shining armor, with a flaming sword in his hand. He tramples the dragon, which is viewed as evil. Orthodox Christians believe that the Archangel Michael protects the souls of the deceased on their way to the Throne. It is also believed that on November 21 (8) the Archangel Michael lowers his right wing into the fires of hell, which at this very moment goes out. And if he is prayed on this day immediately after midnight, then the Archangel Michael can rescue those deceased, whom a praying person prays for, from the infernal abyss. In Russia, the Archangel Michael was also prayed for help when moving to a new place of residence.

The image of the Archangel Michael is also reflected in poetic works. So, he appears in I. Bunin's poem ("Arkhangel $\mathrm{v}$ siiaiushchikh latakh i s krasnym mechom iz ognia" ("The Archangel in shining armor and with a red sword of fire")) and in a poem by Stanislav Minakov, our contemporary ("no, k polku poslednikh dobiraia, khodit Mikhail Arkhistratig" ("but, getting the latter to the regiment, goes Michael the Archangel")).

In the Orthodox tradition, since ancient times, celebrations were held everywhere on Michaelmas when people tried to reconcile with each other. Beer, roast meat, honey, and pies were placed on table. By tradition, they always ate beef or pork jelly. Along with cakes and honey, children were also treated to fruit in order to be healthy next year. According to a popular belief, nothing could be done on this day. The ban on work was lifted only for those people who worked against their will or did good deeds only for the sake of helping others. It was especially important not to chop anything with an axe or cut with a knife on this day, as it was believed that St Michael could be offended. It was on this holiday that people tried neither to quarrel with each other, nor to shout or to swear. Michaelmas was a great occasion to forget all grievances and make peace. Young girls who wanted to get married in the coming year also turned to the Archangel Michael for help. To do this, they brought a cake or bread baked with their own hands to his icon as a sign of their gratitude. According to the old people, after the ritual the girls had got a groom very soon.

On Michaelmas natural signs were also observed. So, if this day was clear, severe frosts were expected soon. Or if wet snow was falling, the spring was expected to be rainy. The old people said that if fasting on the eve of this holiday, a person could have his/her name written on the throne of God.

Yet, the most important thing on this day was impossibility to refuse to help those in need. It was necessary to remember those who might need help, do one's best and try to help a person in need or at least just support him/ her with a kind word. It was believed that on Michaelmas everyone was rewarded according to their merits. People with a lot of sins could be punished from above on this day. Therefore, on the day of the celebration of the Synaxis of the Archangel Michael and the other bodiless powers Orthodox people tried to follow the established church rules.

\section{Iconography of the Image of the Archangel Michael}

There are many icons depicting the Archangel Michael. In iconographic images of different archangels, one can notice some common features. Thus, as beings consisting of light and carrying it, angels and archangels often have a globe or a mirror as one of their attributes. These are the Greek monogram of Christ "IC XC" that is usually inscribed inside the mirror or a semi-transparent image of Christ Emmanuel that is depicted on the belt. In Russia, there was a belief that the archangels learn the will of God through the mirror. That is why the archangels Michael, Gabriel, Raphael and Uriel were often depicted with this object. Archangels were also depicted with trumpets in their hands, the trumpets being a symbol of supreme power along with the rod or scepter. The trumpets symbolized the approach of the 
Last judgment, which they were to announce. The cross, the spear, the cup, and the stick with the sponge are, first of all, instruments of the Lord's passion. The images of these tools are often depicted on the icons of the archangels Michael and Gabriel. Since all the angels and archangels represent the Heavenly Host, there are swords, shields, spears, fire whips, and even axes on the icons with their images.

Russian iconography, which at first was largely based on the Byzantine canons, began to develop new themes and scenes from the end of the $15^{\text {th }}$ century, which in the future will largely determine the uniqueness of the Russian iconographic tradition. At that time, a large number of schools were formed, the schools being different from each other in their individuality. These include the Belarusian icon-painting school with its traditions reflected in the icon, which was kept in the village of Ishimka.

In Bolshoi Ului, the icon of the Archangel Michael was created by Belarussian icon-painting masters. According to the Russian historian Nikodim Pavlovich Kondakov, this school is unique in the world of Slavic Orthodoxy and is an offshoot of the Italo-Cretan icon-painting tradition.

By the end of the $13^{\text {th }}$ century, the Belarusian principalities, weakened by the Tatar-Mongol invasion, gradually began their retreat to the Grand Duchy of Lithuania, which had escaped the Mongol encroachments. For a long time, the Lithuanian princes were quite tolerant of their Orthodox subjects, who made up the majority of the inhabitants of the new state. However, in the $16^{\text {th }}$ century, the situation changed drastically. At that time, represented by the missionaries from the Catholic monastic orders, the West decisively moved to the East with the intention of subjecting Orthodoxy to the papal see. In 1569 , as a result of the Union of Lublin, a new commonwealth was formed with its capital in Grodno. Since that time, Orthodox brotherhoods emerged in major Belarusian cities, which stubbornly resisted the Catholic missionaries' claims. In 1633, this led to the official recognition of Orthodoxy on equal rights with Catholicism. This was also the time of the dawn of the Belarusian icon painting.
Due to Catholic influence and Western masters' involvement in the field of temple architecture and iconography, Belarusian masters started applying picturesque techniques of icon painting of the Western style, as well as using a typical range of scenes for the Catholic tradition. At the same time, the masters tried to preserve Orthodox traditions, which led to the formation of specific local features in iconography. For example, there formed a tradition of covering icons with settings made of different materials (metal, wood, fabric). The sides of the icon were also decorated with the imitation of stucco precious stones and picturesque ornaments (these sides more and more often formed a kind of a frame). National ornaments, objects and details taken from real life (for example, dishes or a cradle) appear in the images of the saints' clothes and other elements. The backgrounds on the icons are quite free compositions, and the elements of the landscape acquire an artistic value in themselves.

In the second half of the $17^{\text {th }}$ century, an attempt to annex Belarus to Moscow Empire was unsuccessful. As a result, residing under the Polish-Lithuanian Commonwealth for a long time, the Orthodox population was oppressed by Catholics. The union was forcibly imposed. In such historical conditions, the Belarusian iconography of the $18^{\text {th }}$ century became the guardian of the Orthodox tradition and one of the forms of manifesting national identity. However, the style of icons was still largely focused on Western painting and incorporated some features of the Baroque, Rococo and classicism. This is most noticeable in some details of everyday realities. As a result, the Orthodox iconographic canon was increasingly saturated with worldly features. Individual paintings, brought from the West or written by the invited Western European masters, suggested new landmarks for Belarusian icon painters. Thus, by the end of the $18^{\text {th }}$ century, the Belarusian icon painting school was a synthesis of Western European and late Renaissance influences with a creative reworking of various national stylistic traditions (Western and Old Russian origin of compositional schemes, a combination of tempera and oil techniques, an appeal to a carved gilded background). 


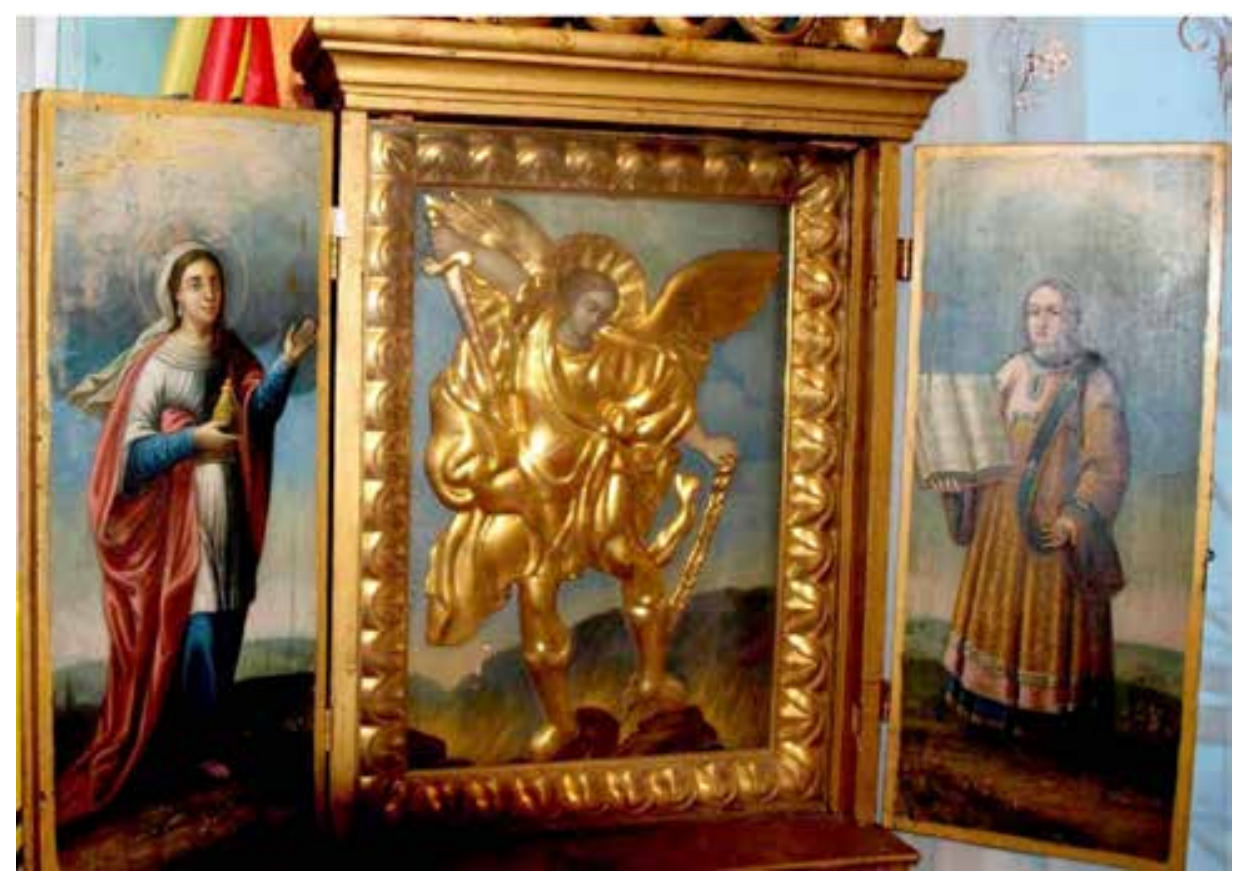

Fig. 1. The icon of the Archangel Michael in St. Nicholas Church in the village of Bolshoi Ului

According to Anna Andreevna Abisova, an art critic and a senior researcher of the Department of Russian Art of the $18^{\text {th }}$ - early $20^{\text {th }}$ centuries of the Krasnoyarsk Art Museum named after V.I. Surikov, the icon in St. Nicholas Church in the village of Bolshoi Ului undoubtedly represents spiritual and artistic value (Fig. 1).

Regarding the features of the image of the Archangel Michael, this icon is strikingly similar to the famous masterpiece "The Archangel Michael defeating Satan" (1635) by the Italian painter Guido Reni, who created it on cardinal Sant Onofrio's order, the cardinal being the brother of Pope Urban VIII. This painting became very popular in Catholic countries, and many Western artists and iconographers willingly copied it. For comparison, below are two reproductions of the paintings belonging to the brush of Guido Reni (Fig. 2) and Antonio Palomino de Castro y Velasco (Fig. 3), both paintings depicting the Archangel Michael.

The continuity of the composition of the paintings and the features of the image of the Archangel Michael is obvious.
The comparison of the reproductions of two paintings with the Belarusian icon justifies the statement that the icon in the village of Ishimka belongs to the $18^{\text {th }}$ century and was created by the Belarusian icon painters in the Baroque style.

\section{The Rite of Veneration of the Icon of the Archangel Michael}

The rite of veneration of the icon of the Archangel Michael, brought from Belarus, was observed by the residents of the village of Ishimka on November 21/8 when the Orthodox Church celebrated the Synaxis of the Archangel Michael and other bodiless powers. This ceremony was common in the village of Ishimka until 2005. Such a long (over a century) preservation of the tradition might have been influenced by the geographical location of the village. It is due to the fact that the nearest church parish is located in Bolshoi Ului at a distance of thirty-two kilometers from the village. Besides, it was necessary to cross the Chulym River to get there. The turbulent nature of this river was precisely the cause why the inhabitants of Ishimka were often completely isolated 


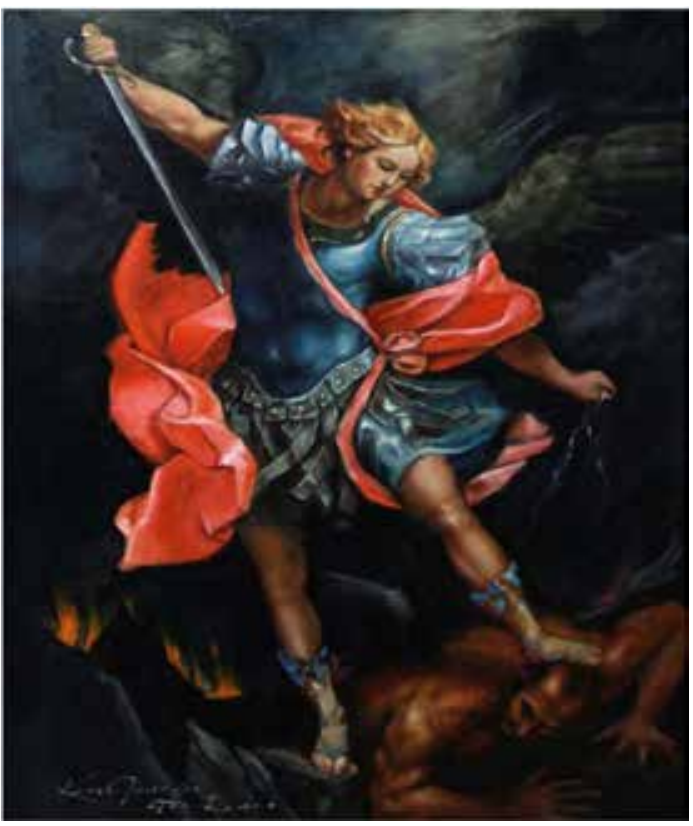

Fig. 2. Archangel Michael.

Guido Reni (1635-1636, Santa Maria della Concezione dei Cappuccini, Rome)

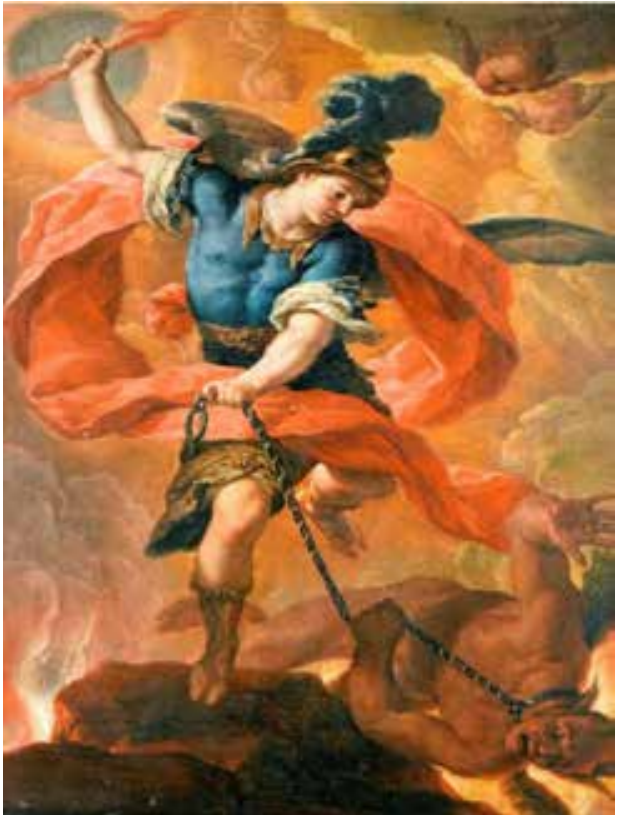

Fig. 3. St. Michael the Archangel Vanquishing the Devil Acislo Antonio Palomino de Castro y Velasco (1690) from other localities and, therefore, were deprived of any opportunity to attend the temple. Thus, most Orthodox holidays were celebrated right in the village. The Synaxis of the Archangel Michael and the other bodiless powers, celebrated on November 21 (8), was not an exception.

The weather on Michaelmas was often different: there were thaws, accompanied by heavy mud, and frosts, causing a thin flimsy ice on the river. Most likely, this is the reason why the icon of the Archangel Michael was not given to the church for a long time, but was kept in the villagers' homes and passed from one family to another.

The issue of passing the icon to a particular family was resolved together on the eve of preparing for the holiday. The representatives from each village family gathered in the house where the holy image was kept for the past year and discussed whether a family from the next house in line was worthy of keeping the icon. To be given such an honour the future keepers of the sanctuary had to live a righteous life throughout the previous year, to keep themselves and their homes in a decent state and moral piety. If the assembly noticed the unworthy behavior of the chosen owners, or insufficient (according to local ideas) cleanliness of their homes, then these people were not approved. For example, if someone from the family abused alcohol or cursed, then the honor of keeping the icon of the Archangel Michael in their home passed to another worthy family.

According to M.I. Rantseva's memoirs (Rantseva, 2012), the rite began on the eve of the celebration of the Synaxis of the Archangel Michael and the other bodiless powers with the sacrament of rolling candles from wax. "People gathered in the house where the icon was. After praying, all those who came there began to roll candles for the holiday, one candle being rolled especially large so that it was large enough for the entire upcoming service," narrates Maria Illarionovna (Rantseva, 2012: 19). In a surprisingly warm and joyful atmosphere, people made scented candles from wax, sometimes adding scented herbs to them. The whole space of the house was filled with the smell of honey, wax and herbs. In the atmosphere of 
the eve of the holiday, when reading prayers in a quiet voice, everyone tried to make his/her candle unique, special, and charging the souls and hearts of those present with light energy. Having finished this activity, the people left for home till morning.

The next morning all the Orthodox residents in Ishimka returned to that house, where the icon was kept, again. The Procession started from it and was made around the village, accompanied by spiritual chants and prayers. Such beginning of the holiday is quite clear, since for the Orthodox the Procession had always been an action performed strictly according to a certain ecclesiastical charter in connection with important events in the life of the church or the country, whether an Orthodox holiday or a tragic event, when people turn to God asking for protection. This is not just a walk from one point to another: it is a sacred event, during which the streets of the village are consecrated, certain chants are performed, and passages from the Holy Scripture are read.

In the village of Ishimka, on a holiday dedicated to the Archangel, an icon with the image of the Archangel Michael was carried at the head of the Procession. According to the local custom, the icon was carried on a rushnik, an embroidered towel decorating the icons. Only the widows could do this. The words they said were: "Mikhailo Arkhailo chudnyi! Mikhailo Arkhailo divnyi! Voin, voin blagodetel', a na tom zha ty svete nam pomoshchnichek budesh! (Mikhailo Arkhailo wonderful! Mikhailo Arkhailo marvelous! Warrior, warrior benefactor, you will help us in the afterlife!"). After this they performed the spiritual verse "Mikhailo Arkhangélo" ("Michael the Archangel") and read the prayers to the Archangel. When the icon of Michael the Archangel was carried through the village, many people, having made a wish, sat down on the road so that the widows carried the icon of the Archangel over them and, thus, in the hope to receive grace and blessing for the upcoming achievements from this icon.

Among various sacred practices that of passing under the icon during the Procession is of particular interest. This custom is quite common and often found in local cults in
North-Western villages of Russia. The believers associate passing under an icon or a shrine with the relics of the saint with the protection of the Holy Virgin. The Mother of God and the Archangel Michael, who accompanies her, are the only patron saints of the sinners. This fact is customary to remember when passing under the icon. In addition, this action symbolizes the protection of the Holy Virgin, her intercession of all believers. At the same time, it means crossing a certain border that divides the space into "sacred" and "profane" zones. By crossing it, the believers take another step on the path to God. Many believe that this custom has a healing energy. That is why it was not without reason that sick people were often either carried under the icon or put on the way of the Procession so that the icon could be carried over them.

Thus, having walked around the village, the residents of Ishimka followed to the house where the icon was to be kept till the next holiday in the coming year. Then, after the prayers, with great joy in their hearts and with a good mood, they sat down to a festive table. People called Michaelmas a well-fed holiday, since there was still a lot of bread stored for the winter, and all the agricultural works were already over. It was believed that on this day (as well as on New Year 's Eve, on a lavish evening) one can eat his/her fill for a whole year. Therefore, the Michaelmas holiday very often continued till the beginning of the Christmas fast (till November 28/15).

\section{Conclusion}

The Archangel Michael is an eschatological image existing through all the stages of the world history that have already been accomplished and are yet to be realized. It manifests the eternal theme of struggle between good and evil (God and the devil), which is destined to end with the triumph of the truth. This image integrates the apocalyptic meaning and the theme of the immortality of the soul, the idea of patronage of the Orthodox people on the way to salvation and establishment of Christianity. It is probably the reason why the villagers of Khodun' carried two icons of the Archangel Michael with them when moving to remote Siberian lands and kept the rite of veneration of 
one of the surviving icons until the beginning of the $21^{\text {st }}$ century.

This article is an attempt to consider the role of the image of the Archangel Michael in the Russian people's life; the meaning and forms of implementation of the rite of worshiping the icon of the Archangel performed on November 21(8) during the Synaxis of the Archangel Michael and other bodiless powers in one of the local migrant traditions of Siberia; the factors that determine such a long existence and preservation in local traditions of the rite with specific forms of its implementation. Thus, the main goal of the article was to identify the characteristic features of both the iconography of the Belarusian icon of the Archangel Michael and the local version of the rite of veneration of this icon, this goal being achieved in the course of the research.
The opinion of competent experts supports our confident statement that the Belarusian icon brought to the village of Ishimka in Bolsheuluisky district of Krasnoyarsk Krai has obvious historic and artistic value, and the rite of veneration of this icon, which was preserved in a living tradition until recently, has a unique local flavor.

Nowadays we can claim a symbolic meeting of an outgoing Orthodox tradition of the village with a new urban religious practice. The younger generation of the believers is getting increasingly interested in the old village rites and customs and willingly accepts them. For modern Orthodox youth who seek to learn the piety of the church and respect their ancestors' faith in ancient icons, the memory of once-existing Orthodox rites is very important in their spiritual development.

\section{References}

Afinogenova, O.N. (2008). Kul't Arkhangela Mikhaila v Vizantiiskoi Imperii [The Cult of the Archangel Michael in the Byzantine Empire]. Moscow, 18 p. Available at: https://lib.rsl.ru/viewer/01003457533\#?page $=1$ (accessed 20 November 2018).

Apokrificheskie Evangeliia [Apocryphal gospels] (2011). Kharkov, Folio, 231 p.

Benchev, I. (2005). Ikony Angelov. Obrazy Nebesnykh poslannikov [Icons of Angels. Images of Heavenly messengers]. Moscow, Interbuk-biznes, $255 \mathrm{p}$.

Bolotov, V.V. (1892). Mikhaǐlov den'. Pochemu sobor sv. Arkhistratiga Mikhaila sovershaetsia 8 noiabria [Michael's day. Why is the Synaxis of St. Michael celebrated on November 8]. In Eortologicheskii etiud. Khristianskoe chtenie [Eortology etude. Christian reading], 12, 595-644.

Dionisii Areopagit (2002). Sochineniia. Maksim Ispovednik. Tolkovaniia [Collection of works. Maxim the Confessor. Interpretations]. Saint-Petersburg, Aleteiia, 854 p.

Gil'ferding, A.F. (1873). Onezhskie byliny [The Onega folk epics]. Saint-Petersburg, Tipografiia Imperatorskoi Akademii Nauk, 732 p.

Grigorii Palama. (2006). Sto pia'desiat glav [One hundred and fifty chapters]. Krasnodar, $224 \mathrm{p}$.

Rantseva, M.I. (2012). Obriad pochitaniia ikony Arkhangela Mikhaila v d. Ishimka Bol'sheuluiskogo r-na Krasnoiarskogo kraia [The rite of veneration of the icon of Archangel Michael in the village of Ishimka in Bol'shoi Ului district of the Krasnoyarsk krai]. Achinsk, Sound recording, From A.V. Trofimov's personal archive.

Trofimov, A., Sapsuiev, A., Voitkevich S. (2018). The Problem of the Origin and Development of Spiritual Verse as a Genre. In Proceedings of the 4th International Conference on Arts, Design and Contemporary Education, 232, 9-12. DOI: https://doi.org/10.2991/icadce-18.2018.3

Tychinskaia, P.A. (2012). Obraz Arkhangela Mikhaila groznykh sil voevody v russkom iskusstve pozdnego srednevekov'ia [The image of the Archangel Michae, a voivode of the threatening forces, in Russian art of the late middle ages]. Moscow, 26 p. Available at: https://dlib.rsl.ru/viewer/01005042611\#?page=1 (accessed 12 March 2019).

WikiReading (2019). Obychai prokhozhdeniia pod ikonoi: ego formy i funktsii [The custom of passing under the icon: its forms and functions]. In Religioznye praktiki v sovremennoi Rossii [Religious practices in modern Russia]. Available at: https://religion.wikireading.ru/72527 (accessed 5 April 2019). 


\title{
Обряд почитания иконы Архангела Михаила в деревне Ишимке Большеулуйского района Красноярского края
}

\author{
A.B. Трофимов, В.В. Чайкина \\ Сибирский государственный институт искусств \\ имени Дмитрия Хворостовского \\ Российская Федерачия, Красноярск
}

Аннотация. В статье затрагивается проблема сохранения аутентичной традиции. В деревне Ишимке Большеулуйского района Красноярского края до недавнего времени существовал обряд почитания иконы Архангела Михаила. Повествование об этом обряде записано в фольклорной экспедиции от Марии Илларионовны Ранцевой в 2012 году. Ею же напет и духовный стих об Архангеле Михаиле, который исполнялся в контексте обряда почитания его иконы. Этот материал впервые рассматривается в нашем исследовании, чем обусловлена его значимость и научная новизна. Поскольку русская фольклорная традиция в настоящее время стремительно угасает, материалы, записанные от Марии Илларионовны Ранцевой, являются бесценными.

Архангел Михаил - один из самых любимых русским народом представителей Небесного мира. Он считается главным Архангелом. Имя его в переводе с древнееврейского означает «Кто как Бог». В православии его называют Архистратигом, поскольку он является главой Небесного воинства Ангелов и Архангелов. Кроме того, Архангела Михаила воспринимают как покровителя путешественников. Также на Руси Архангелу Михаилу молились о помощи при переходе на новое место жительства. Именем этого Архангела названо много русских храмов, в каждом из них есть иконы с его образом. В русской иконописи сложилось множество местных школ. Икона Архангела Михаила, о которой идет речь в данной статье, написана мастером белорусской школы иконописи. В начале $\mathrm{XX}$ века эта икона была перенесена крестьянами одной из белорусских деревень в сибирскую деревню Ишимку. Обряд почитания иконы Архангела Михаила сохранялся в этой деревне до начала XXI века.

Ключевые слова: Архангел Михаил, икона, обряд, традиция, Сибирь, Ишимка, М.И. Ранцева.

Научная специальность: 17.00.09 - теория и история искусства. 